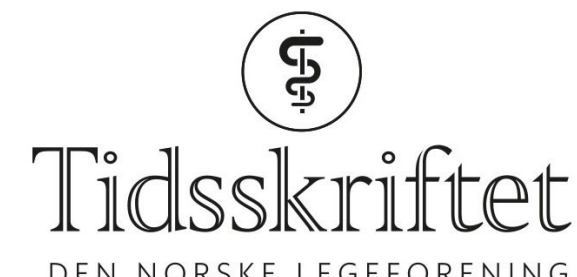

DEN NORSKE LEGEFORENING

\title{
Immun: vær så god!
}

ANMELDELSER

INGVILD J. LAEGREID

Konstituert overlege, Immunologi og transfusjonsmedisin

Laboratoriemedisin, Universitetssykehuset Nord-Norge

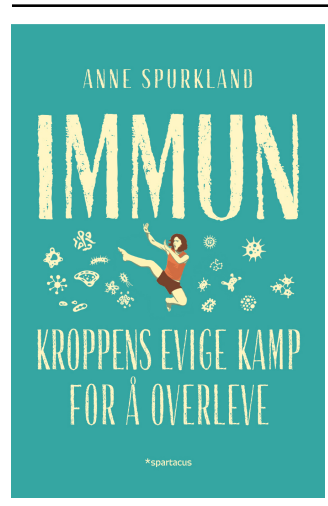

Anne Spurkland

Immun

Kroppens evige kamp for å overleve. 416 s, ill. Oslo: Spartacus Forlag, 2017. Pris NOK 399

ISBN 978-82-430-0830-4

På bølgen av populærvitenskapelige bøker om ulike deler av kroppen kommer Immun seilende. Bøker i denne sjangeren er ikke lærebøker i ordets rette forstand, men her er det likevel mye å lære for de som er interessert i kroppens forsvar mot ytre og indre trusler. Målgruppen er bred og omfatter også de som er godt kjent med immunologi fra før, ikke minst som en påminnelse om historien bak og grunnlaget for faget.

Boken delt i seks hoveddeler med underkapitler starter med mikrobene, oppdagelsen av disse og hvordan de kan gjøre oss syke. Slik settes scenen for immunforsvaret og alle oppgaver det har utviklet seg for å løse. Det er noen få, enkle illustrasjoner for å klargjøre strukturer og konsepter. Ellers bæres innholdet av et lettforståelig og nøytralt, men likevel personlig språk.

De litt over 400 sidene dekker det vesentligste for en grunnleggende forståelse av immunsystemet, uten at boken oppleves for lang eller detaljert. For den mer investerte leser er det rikelig med referanser som kommer til slutt. Avslutningsvis finnes også ordforklaringer, persongalleri og en smørbrødliste over forfatterens tips til et godt immunforsvar, forfriskende uten supermat, detox eller andre helsetrender.

Hver celle og hvert molekyl har sin plass for at immunforsvaret skal kunne gjøre jobben sin, 
og forfatteren lykkes godt med å vise sammenhengen mellom disse og tegne det store bildet. Her serveres historier om hvordan og av hvem kunnskapen om immunforsvarets bestanddeler og deres oppgaver har blitt oppdaget. Vi møter store navn fra inn- og utland hvis bidrag til immunologien, og ikke minst folkehelsen, har vært enorme. Det er inspirerende å lese om oppdagelsen av ting som nå er lærebokstoff, men som for ikke lenge siden var banebrytende nyheter. Vi som jobber i faget står virkelig på skuldrene til kjemper. I teksten finnes også flere pasientfortellinger og historier fra forfatterens eget liv og bakgrunn naturlig føyet inn i de temaer som omtales. Her er eksempler på hva som kan skje når noe mangler og når immunforsvaret retter skytset mot feil mål eller tar for hardt i.

Immunologi er gøy, og med denne boken gjøres kunnskapen tilgjengelig for flere. Anbefales!

Publisert: 12. juni 2018. Tidsskr Nor Legeforen. DOI: 10.4045/tidsskr.18.0171

(C) Tidsskrift for Den norske legeforening 2020. Lastet ned fra tidsskriftet.no 